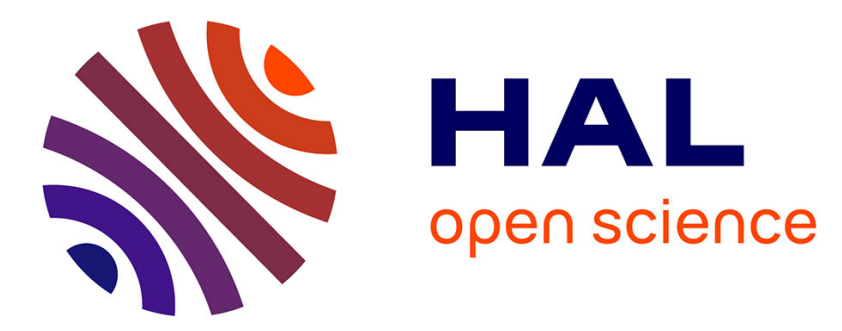

\title{
National institutional systems' hybridisation through interdependence. The case of EU-Russia gas relations
}

Mehdi Abbas, Catherine Locatelli

\section{To cite this version:}

Mehdi Abbas, Catherine Locatelli. National institutional systems' hybridisation through interdependence. The case of EU-Russia gas relations. Post-Communist Economies, 2020, 32 (4), 10.1080/14631377.2019.1640991 . hal-02272171

\section{HAL Id: hal-02272171 \\ https://hal.science/hal-02272171}

Submitted on 27 Aug 2019

HAL is a multi-disciplinary open access archive for the deposit and dissemination of scientific research documents, whether they are published or not. The documents may come from teaching and research institutions in France or abroad, or from public or private research centers.
L'archive ouverte pluridisciplinaire HAL, est destinée au dépôt et à la diffusion de documents scientifiques de niveau recherche, publiés ou non, émanant des établissements d'enseignement et de recherche français ou étrangers, des laboratoires publics ou privés. 


\title{
National Institutional Systems' Hybridization through Interdependence. The Case of EU-Russia Gas Relations
}

\author{
Abbas Mehdi and Locatelli Catherine
}

March 2019

\begin{abstract}
The interdependencies between the EU and its external natural gas suppliers and Russia question the transformative impact of interdependence linked to hybridization processes. Our approach combines theories of institutional change, and French Regulation Theory. These approaches lead to a new look to characterize the way in which the confrontation of two regulatory systems (EU and Russia) is resolved today. The importance of the European market leads however to an adaptation of the Russian governance model for gas exchanges. But it also implies a transformation of the European model. The competitive norm acts as a lever to bring about hybridization of regulations in the Russian gas sector and EU energy policy.
\end{abstract}

Key words: Institutional hybridization, natural gas exchanges, relationship between EU and Russia, institutional change.

JEL : F55, L22, L72, Q37

\section{Introduction}

The problems related to actors' conflicting preferences involved in the EU-Russia gas interdependence are well known ${ }^{1}$. They result from the opposition between a large importer and consumer of natural gas - the EU - and a key exporter and producer Russia. This preferences' antagonism is not merely functional. It is also related to specific gas sector characteristics: economies of scale, network industry, regional organization of markets and non-renewable resources. Moreover, domestic institutional contexts determine the forms of competition, namely the way in which long-term organizational relations between State and companies, either domestic or foreign, the relations between autonomous and fragmented actors engaged in production process and the relations to the world market, i.e. the interstate competition, are organized ${ }^{2}$. However, in view of the

\footnotetext{
${ }^{1}$ There is a wealth of literature on this topic, in particular Casier (2011); Kuzemko and al (2012); Kratochvil and Tichy (2013); Romanova (2014); Van Der Meulen (2009); Harsem and Claes (2013).

${ }^{2}$ We take this definition of competition as an "institutional form" from the French Regulation Theory (FTR). The key Regulationist concept is the "mode of regulation" which refers to institutional or structural forms, institutionalized compromises, laws, rules and norms that support national growth strategy. Five main institutional forms shape a growth strategy: wage relations, money, the State, competition regime and the international regime. These institutional forms are mediated by the State which secures the overall
} 
institutional shifts in EU and Russian markets, the confrontation between their respective preferences merits re-appraisal.

Following Russia's refusal to sign the Energy Charter Treaty and the deepening of liberalization process of European gas industries, the analyses carried out implicitly focused on the confrontational implications of EU-Russia interdependence. These analyses put forward an "institutional hiatus" and the inability to define an energy workable governance structure (Godzimirski, 2015; Van Der Meulen, 2009; Romanova, 2014; Boussena and Locatelli, 2013). The question of the confrontation of national institutional system and the overlapping of rules in interdependence remains central in analysing UE-Russia relationship. However, we consider that it does not exhaust the whole problem of the interdependence. New approaches in this field (Farrell and Newman, 2016; Newman and Posner, 2015) lead to a new look to characterize the way in which the confrontation of two regulatory systems (EU and Russia) is resolved today to the benefit of the EU given the size and the specificities of its gas market. These approaches then invite us to question the transformative impacts of interdependence on the actors' strategic behaviors and the opportunity structure available to EU's historical suppliers. They also shed light on the changes that can be observed today in the European energy policy vis-à-vis its main suppliers and specially Russia.

The originality of our approach is to combine theories of institutional change, particularly the works of K. Thelen $(1999,2003)$ and French Regulation Theory. This allows us to adopt a power distributional approach to institutions (Hall, 1986; Thelen, 1999 and 2003; Amable, 2005; Boyer, 2015) which drive us to treat institutional arrangements as devices for regulating distributional conflicts associated with actors' strategic behaviour regarding both institutional arrangements and the ways they interpret and implement these arrangements ${ }^{3}$. In this sense, we are moving away from functional approaches to institutions which explain their emergence, persistence and transformation by their capacity to reduce transaction costs and to control opportunistic behaviour in principalagent relationship or in an iteractive game equilibrium.

This is why, institutional change is a produce of hybridization and incremental adaptation. By hybridization, we qualify the process of mutual adaptation of behaviors and institutions that takes place when two economic spaces are in interdependence (Boyer et alii, 1998). However, we do not consider hybridization as an "unintentional process" (Boyer, 2004). Rather, it is an endogenous process produced by market actors' strategies and behaviors. These adapt to contexts' evolutions and to uncertainties linked to the incompleteness of the institutional arrangements. Thus, hybridization does not refer to a state but to a dynamic and conflictual process of coevolution in both institutional arrangements and actors strategic behaviors. We consider that interdependence plays a strategic function in the process of hybridization of national institutional frameworks. It acts as a catalyst for rescaling and reframing institutional forms. Interdependence refers to the way in which local, regional, national and supranational spaces are articulated and how the relationships between them are constructed. Actors are inserted in an

complementarity of different institutional forms (Boyer, 1990). For an introduction to the methods, concepts and analytical tools of the French Regulation Theory, see Boyer (1990, 2000), and Boyer, Saillard (2002). For a synthetic presentation of the FTR see Jessop (ed.) (2001) and Jessop and Sum (2006).

\footnotetext{
${ }^{3}$ We ove the hypothesis of enforcement of institutional rules as a variable in the analysis of institutional change and the struggle over the meaning, application and compliance in relation with the resource allocation institutional rules entail to Mahoney and Thelen (2010).
} 
"articulated nesting of spatial and institutional scales" which "has the potential of transforming national forms of regulation" (Mistral, 1986). Interdependence renews the sources of institutional changes (Djelic and Quack, 2003), generates power resources, constraints and opportunities (Keohane and Nye, 1977; Keohane, 2002) for states as well as for non-state actors (firms in our case); and shapes the type and practices of competition.

Therefore, confrontation between EU and Russian preferences regarding gas regulation is a complex and contradictory process which does not fit into the mould of the one-bestway model nor yet the one-size-fits-all. The EU-Russia interdependence is built upon the coexistence of distinct gas models suited to different institutional contexts with distributive issues associated with the reform and the liberalization of national gas sectors. These distributive issues explain that power relations play a major role in the form and the substance of the interdependence. For example, the EC has always questioned the potential Gazprom's market power in Europe and the links (real or supposed) between the company and the Russian State (Goldthau and Sitter, 2015a and b; Jansen et al., 2012; Sagen and Tsygankova, 2008). This is why, Gazprom, in order to maintain its market share in the EU, is obliged to plays the competitive game advocate by EC. As a result, despite Russia's refusal to accept EU regulations, the competitive norm is spreading to Russian transnational actor, hybridizing Russian gas regulatory framework. In doing so, this process, in return, is driving a hybridization of the EU policy.

The article is divided into five sections. After the introducing one, the second focuses on the systemic implications of the European competitive norm for energy sector regulation. The third section explores Gazprom's adaptation to the EU's competitive rule. The fourth section addresses the issue of hybridization in interdependence through an analysis of the evolution of Gazprom's objectives, preferences and interests and its consequences for the EU's competitive model. The concluding section considers the implications of hybridization for the future of world gas markets and EU-Russia energy relations.

\section{I - The European Union's Competitive Norm and its Systemic Implications for the Regulation of Energy Sector}

The European Union is one of the main advocates of the use of competition based on the rule of law of international economic relations (Skalamera, 2016). This preference is rooted in the history of European integration. The move from a 'common' to a 'single' market (1986), and then on to economic and monetary union (1993), was achieved by dismantling national forms of regulation. European states have historically favoured competition as a mechanism for coordinating and overtaking national interests (Ehkrman, 1992; McGowan and Wallace, 1996). In 1986 the EU preference for competitive and liberalized markets became its primary objective aiming at "greater integration, free from barriers to trade, of the internal energy market with a view of improving security of supply, reducing costs and improving economic competitiveness" (CEC, 1988).

The European Commission has turned competition into the prime institutional instrument for regulating interaction between national and international actors. Its objective is to build and manage markets that are autonomous with regard to member states and based on undistorted competition (Drexl, 2011; Gerber, 1994). The EU stands out for having built its priorities regarding competition and market autonomy into its constitution. In so doing it has forged a specific connection between politics and the economy, transferring 
regulatory and supranational (the political dimension) sovereignty while at the same time deploying a competitive norm and growing market autonomy (the economic dimension). This preference carries through into the way the EU sees its role in the international arena and its economic relations with abroad (Smith, 1996; Damro, 2015). Since 1998 with the adoption of the first European directive on the liberalization of gas markets, the European Commission has constantly been careful to articulate rule-based energy regulation with a unified competitive gas market ${ }^{4}$.

The EU ranks as a world power mainly because of the market it controls, or in other words, the trade outlets it represents for exporters the world over. The size of its market is a key factor in its strategy of interdependence, taking advantage of the fact that competitive opening, in the presence of imperfect markets, favours large markets (Krugman and Helpman, 1985) ${ }^{5}$. Access to the European market becomes a key instrument of the EU's bargaining power. This explains the place of the common trade policy (one of the few truly EU policies) in its policy transfers and rules exportation strategy (Manners, 2002, Howse and Nicolaïdis, 2003). Trade policy remains, however, hierarchically second compared to competition policy since it is into the larger framework of open regionalism and a multilateral trading system, founded on unrestricted access to markets. Free trade is consequently a constituent part of the competition policy, rather than the opposite. The Commission endorses the argument that competitive opening makes markets more contestable (Baldwin et ali, 1992; Graham and Lawrence, 1996; Damro, 2006).

However, New Trade Theory (also named International Industrial Economics) explains that, in the presence of increasing differentiated returns, liberalization may lead, in dynamic, to the formation of a monopoly (Grossman and Helpman, 1991). Greater opening or exposure to competition is not necessarily beneficial, nor even theoretically sound, in the presence of uncertainty and imperfect markets. The conditions of opening consequently count more than opening itself highlighting the possibility of multiple equilibria in an open economy. This in turn leads to a process of equilibria selection based on power relations between actors and what the authors name 'strategic actions' (Brander and Spencer, 1985; Krugman, 1984). This explains why public intervention cannot restrict itself to framing and maintaining rules of free competition, because competition itself leads to redistribution of activities and sectors to the detriment of one of the two actors (Gomory and Baumol, 2000 ; Palley 2006).

\section{- The competitive regime: the keystone of EU energy policy}

The competitive rule is the keystone of the EU energy policy in particular, concerning its relationship with external suppliers $(\mathrm{EC}, 2006)^{6}$. Liberalization processes profoundly

\footnotetext{
${ }^{4}$ Successive enlargements (2004, 2007, 2014), the European Economic Area for Norway (1994 and its two revisions in 2003 and 2007), the third TEP (2009), are key dates in the European project to internationalize of its norm.

${ }^{5}$ We have to remember that the main argument in Cecchini's (1988) report on the "cost of non-Europe" and
the benefits of the European single market is inspired by the work of Krugman (1979) and Krugman,
Helpman (1985) on the New International Trade Theory. It is based on economies of scale, the
differentiation of goods and business strategies to create national comparative advantages.

6 This formed the starting point for the discussion on a coherent EU energy policy which led to the formulation of Article 194 TFEU within the Treaty of Lisbon (2009, online).
} 
change the preferences of the EU, making energy a commodity like any other, in other words a private good handled by competitive markets and no longer a public or strategic good (Kuzemko, 2014). Such markets are seen as a mechanism of efficient governance for network industries, particularly gas and electricity (Buch-Hansen and Wigger, 2010; Goldthau and Sitter, 2015a). In contrast to electricity markets supplied from inside the EU, reforming the gas sector raises specific problems. More than half the gas consumed in the EU is supplied from outside the single market, primarily by an oligopoly: Algeria, Russia, and Qatar.

From the international political economy of the European gas supply, two conclusions emerge. Firstly, in a liberalized environment with high import dependency and an oligopolistic structure of gas supply, the energy security (price and volume) is a key and specific problem. A major shortcoming of the market is the possible market power of a supplier (Goldthau and Sitter, 2015b). Given the size of its market share a supplier could alter the conditions of competition. Therefore, with this oligopolistic structure, it is essential for the EU to diversify its sources of supply. Secondly, reforms to liberalize the gas sector are incomplete. With outside suppliers holding a large share of the market, yet beyond the reach of the EU regulatory framework, reforms have not affected the whole of the gas supply chain. Risks may arise, particularly in terms of incentives for hydrocarbon producers (adequate investment in renewing their reserves, developing infrastructure and such). The question of the connection between the new institutional architecture of EU gas markets and its suppliers is consequently crucial.

The EU's governance project with regard to its external gas suppliers is based on exporting to third-countries its institutional arrangement for gas markets. This arrangement is rooted in competitive market, vertical de-integration of the industry and unbundling of transport networks. The Energy Charter Treaty (1991) but also the Strategic Partnerships ${ }^{7}$, the Energy Community Treaty (2005) and finally the Energy Union (2015) target to bind non-member states to the regulations and European laws. The Commission's interdependence strategy aims to « ordoliberalizing the neighbourhood ${ }^{8}$. The Commission believes that competitive and interconnected markets, along the lines of those defined in its three energy packages (Gas directives of June 1998, June 2003 and the 2009 Energy-Climate Package) are a more effective way of guaranteeing the energy security (price and volume). More specifically, it maintains that exporting its competitive governance model is a means of remedying (at least in part) the shortcomings of the market. It is also a mean to complete the gas reform by liberalizing the upstream (external) part of the gas chain. In so doing, the EU aims to boost the efficiency and problem-solving capacities of its liberalization policies (Lavenex, 2004). Ultimately, it seeks to transform its suppliers' energy governance (Keating, 2012) and roll out a system of common rules coupled with a high degree of institutionalization (Lavenex and Schimmelfennig, 2009). These treaties are a mean to enforce economic integration and supranational policy, with a view to institutionalizing an international market system (Andersen and Sitter, 2016). Even when the EU acknowledged that there are market failures associated to energy, it insists that market instruments are preferred as measures to address such failures (EC, 2010).

\footnotetext{
7 Transit issues, organizational reforms (Gazprom's unbundling), prices are at the heart of the partnership negotiations discussed from 2000 between the EU and Russia.

${ }^{8}$ It is used by R. Roccu (2018) to describe the EU's strategy for promoting regulatory reform in the southern Mediterranean countries.
} 


\section{II - Gazprom's Adaptation Strategies to the EU's Competitive Norm}

The EU's efforts to export competition-based regulation and its 'gas model' raises the question of the legitimacy of exported rules (Godzimirski, 2015; Newmann and Posner, 2015; Manners, 2002), and more broadly the issue of whether this model can be complementary and consistent with Russia's institutional environment.

\subsection{The EU's strategy of interdependence reveals a conflict of preferences}

In the 1990s and 2000s a competitive regulation of the Russian gas sector could be questioned by weakness of the rule of law (poorly defined ownership right, contractual and taxation problems), low regulated domestic gas prices (sometimes lower than the production costs) and the development of non-monetary coordination relations (barter deal and non-payment).

The "Gazprom model", a vertical integrated company with a monopoly of exports and transports, competitive fringes in specific segments of the Russian gas market, is an organizational and institutional response to the institutional specificities of the Russian economy. It allows a minimal industrial coherence (inter-industrial relations) and a social consensus (Locatelli, 2014). So attempts by the EU to export its competition-based regulation to Russia have mainly ended in failure, witness the latter's refusal to ratify the Energy Charter Treaty.

In the interdependence, the "Gazprom model" poses three main problems regarding the UE preference. Firstly, Gazprom's massive share of the EU market - the basis of its supposed market power ${ }^{9}$ - is largely due to the fact that it is currently the only Russian gas export company by pipeline. Secondly, the State's $51 \%$ share in the company raises the specific problem of security as Gazprom, partly, represents the interests and preferences of the State (Locatelli, 2015). Lastly, the access modalities to the Russian hydrocarbon resources for international companies are also seen as a specific risk. The relevant rules have been tightened up for foreign investors. State companies (Rosneft, Gazprom) must be in the consortia that develop strategic hydrocarbon reserves (Adachi, 2009 ; Fortescue, 2010). In addition, the production-sharing agreements, which international oil companies see as the legal framework best suited to investments abroad, have been sidelined ${ }^{10}$.

The interdependence opens up an arena for institutional confrontation between the EU's preference for competition as a mean of managing its gas exchanges with Russia, and the preference of Gazprom (and the Russian State) for bilateral gas exchanges and a downstream integration on the European market through asset swaps (See Box 1). This institutional confrontation has more precisely focused on the issue of long-term contracts. EU's liberalization processes call into question the institutional arrangement - the TOP (Take or Pay) contract - which organises most of the exchanges between Russia and EU. These contracts, largely analysed in the economic literature (Creti and Villeneuve, 2004;

\footnotetext{
9 The link between market power and market share has nevertheless given rise to much debate (Kaplow, 2015).

${ }^{10}$ These contracts include fiscal provisions specific to each agreement, leaving no room for changes to suit the tax regime of the host country.
} 
Hubbard and Weiner, 1986), solve most of the contradictions and conflicts linked to the interdependence by sharing the price and volume risks between seller and buyer and allowing development of stable gas markets (Boussena, 1999).

The EU set out to make the competitive norm the main instrument for managing its relation with external suppliers. In this logic, TOP contracts are expected to substantially change. Some clauses (such as the final destination clause) are seen as creating entry barriers and inhibiting competition. As a result, they can no longer be included in natural gas supply contracts (Nyssens et al., 2004). Other clauses are re-negotiated to achieve greater flexibility (shorter contracts, more leeway on take-or-pay and volume). Prices and the indexation formula have been a crucial issue in debate on TOP contracts. The price in traditional long-term TOP contracts results from bargaining between sellers and buyers, governed by a rationale that combines netback and cost-plus approaches with updates linked to indexation to the price of crude oil and petroleum products (Boussena et Locatelli, 2019). This is in contradiction with the aim of liberalized market to define a market price for natural gas that results from the confrontation of supply and demand in a spot market (hub).

These new forms of trade - updated TOP contracts, development of spot markets and gas hubs - have a significant redistributive impact. They entail a new approach to how price and volume risks are shared between exporters and importers. According to Gazprom, these changes may alter the risk sharing to the disadvantage of producers (Corbeau and Yermakov, 2016). On the one hand, demand for gas will be guaranteed for a shorter period. Yet such security is essential for producers, which must cope with risky, capitalintensive investments to develop new gas fields and build new pipelines. On the other hand, integrating spot prices in price indexation formulas may lead to significant price volatility, which may in turn severely affect the investment strategy of producers. In this context, Gazprom has defended conventional TOP contracts, which cover more than $80 \%$ of the gas it supplies to the EU (Komelev, 2013).

\section{Box 1: Institutional conflict over "Gazprom's downstream strategy" in the EU market}

In the 1990-2000's Gazprom develop a strategy to gain a direct access to end-consumers through acquisition of assets in order to secure its market shares, without needing to sell gas through hubs (Boussena and Locatelli, 2011). This strategy consist mainly of setting up or taking shares in joint ventures with European partners.

Regulations introduced in the Third Climate and Energy Package of 2009 hindered Gazprom's policy of downstream integration into the gas supply chain of the EU. The European rules on unbundling transport limit the company's ability to control pipeline networks to deliver Russian gas and thus reach end-consumers (Willems et al., 2010). On the grounds of energy security, the third-country clause (also known as the 'anti-Gazprom' clause) enables discriminatory treatment of foreign investments. Companies owned by foreign investors must demonstrate that their investment strategies do not jeopardize the security of the EU. Gazprom considers this as a real barrier blocking investment in the EU and its strategy of international development. For the company and the Russian state, this is contrary to the most favoured nation clause, a rule advocated by the World Trade Organization (Cottier et al., 2010; Austvik and Lembo, 2017). In 2014, Russia lodged a complaint with the WTO on this issue. In November 2018, WTO has considered that some aspects are not in line with its regulation: for example the EU's projects of common interests (gas pipelines) which receive financial support. This is it is the same of the regulation that aimed to limit the share of Russian gas to 50\% in some gas pipelines (OPAL). 


\subsection{The reactive hybridization of Russian institutional gas model}

The EU-Russia gas interdependence is forcing the Russian company to adapt to the EU's new regulations. Europe, with $70 \%$ of its exports, is its main gas export market. The infrastructure constraints (network industry) limit (in the short term) its markets diversification strategies ${ }^{11}$. Therefore, Gazprom must adapt to the new EU's regulations and more generally to changes in the European gas environment.

Since the beginning of 2010, the Gazprom's strategies are changing because of the surplus of natural gas supply and the systemic competition linked to the credible threat, on its market share, of the development of American shale gas. Maintaining market share - the top priority for Gazprom (and Russia) - mainly depends on its ability to find its place in the competitive game of the EU gas market. In 2009-2011 its long-term contracts prices were substantially higher than spot prices and Gazprom found itself acting as a residual supplier on spot markets, above all in the keenly competitive market of Northwestern Europe. When the prices on European hubs permitted, liquefied natural gas tended to compete with, or indeed supplant, the flexible volumes in Gazprom's long-term contracts.

Building on Russian comparative advantages - low delivery costs to the EU compared to the cost of the LNG exports (except from Qatar) ${ }^{12}$ - Gazprom develops a strategy to restore its competitiveness and preserve, or even increase, its market share (table 1). This strategy mainly entails updating its long-term contracts. Gazprom modifies partly the price indexation formula with the aim is to close the gap between prices resulting from indexation formulas in TOP contracts and hub spot prices (TTF and NBP) ${ }^{13}$. Furthermore from 2014 onwards, with indexation formulas pegged to oil prices, which fell steeply, the price in Russian long-term contracts necessarily dropped. Finally, in 2016, devaluation of the Russian rouble accentuated this downward trend. The price of Russian gas (at the German border), which stood on average at $\$ 14.5 / \mathrm{MBtu}$ in 2008 , fell to $\$ 9.75 / \mathrm{MBtu}$ in 2014 and less \$7/MBtu in 2015 - 2016 and around \$7/MBtu in 2017. In May 2018, it was $\$ 7.19 / \mathrm{MBtu}$ for a spot price of $\$ 7.3 / \mathrm{MBtu}$ on the NBP and \$7.42/MBtu for the TTF. A greater flexibility on offtake and volumes covered by TOP contracts has been added ${ }^{14}$. This response yielded a substantial increase in Gazprom exports to the EU. By 2017, they stood at 194.4 Bcm, compared with 162.6 Bcm in 2015 (Gazprom Export, 2018). The Russian share is now over $40 \%$ of the EU external supply. Another important indicator

\footnotetext{
${ }^{11}$ Asia and China in particular could be an important outlet. To date, volumes remain limited to LNG exports from Sakhalin and Novatek (less than $20 \mathrm{Bcm}$ ). The commissioning (at the end of 2019) of the first Russian gas pipeline to China, the Power of Siberia, will only partially overcome the constraint. Its capacity of $38 \mathrm{Bcm}$ is in no way comparable to Gazprom transport capacity to Europe, more than $200 \mathrm{Bcm}$.

${ }^{12}$ Qatar has the lowest cost for delivering LNG to the EU. According to Rogers (2017), it is comparable to that of Russia (gas pipeline) but its production capacity is currently restricted by a moratorium. It should substantially increase in the future. The delivery costs of US LNG exports, covered by Cheniere contracts, are also among the lowest, though still higher than Russia's (see Box 2). Norway also enjoys relatively low production costs but has only limited scope for substantially and durably increasing exports to the EU. The same is true of Algeria.

13 The company has adjusted components of the indexation formula by reducing the base price or by changing relative weight of the different petroleum products in the price the price and lowering the coefficients allocated to each of these products.
}

${ }^{14}$ Henderson and Mitrova (2015) quote a figure of $70 \%$ as the minimum for TOP. 
is that, over the two-year period starting in February 2016, only 12\% of American LNG exports entered the EU, despite high gas demand in 2017.

\section{Table 1: Evolution of Gazprom's market share in EU gas imports}

In the EU, Gazprom complies with the new regulations: capacity reservation, downstream strategy, adaptation of the LT contracts. Gazprom adjusted the operation of the relevant sections of its gas pipelines (particularly Yamal-Europe) to conform to the requirements of the Third Climate and Energy Package (notably regarding third-party access to the network and setting up a transmission system operator). It has also removed from its contracts the final destination clause deemed by the EU to be anti-competitive.

The EU failed, contrary to its original objective, to export its regulatory model of competition to Russia. However, in spite of this given the gas interdependencies and its importance as an outlet, it is able to influence, or even normalize, the behaviors and regulation of its main suppliers (Meunier and Nicolaïdis, 2006; McGowan and Wallace, 1996). By this mean, the EU is disseminating its competitive norm for regulating gas markets. Gazprom was initially forced to adapt defensively to the new institutional context. In doing so, a process of hybridization is triggered based on the structural evolutions of the gas market and on the interplay of actors' strategies with respect to the form and substance of the competitive model.

\section{III - The Competitive Norm as a Factor of Institutional Hybridization}

The new conditions of interdependence have gradually upset the goals, preferences and behavior of the two actors in the EU gas market. Interdependence has prompted Gazprom to adopt increasingly commercial strategies in an effort to adapt to a competitive regime in which issues of cost, competitiveness and, consequently, efficiency are crucial. But it has also raised an essential question for the EU: how to limit Russia's market share. Given the size (reserves and output) and competitive advantages of Gazprom, the EU has found that the interplay of competition is far from adequate to contain the company's market share. Simply in economic terms US exports of LNG (and all the 'remote' sources in Africa or Australia) cannot offer an alternative to Russia's gas supply.

\subsection{A proactive hybridization: Towards a competitive Gazprom?}

Following a phase in which it has adapted its practice to suit the EU's competitive regime, various factors suggest that Gazprom is now adopting institutional innovations and strategies that would enable it to take advantage of competition in the EU market.

In the event of massive US LNG exports, ${ }^{15}$ Gazprom is in a position to define strategic behavior thanks to its comparative and competitive advantages. With the scale of its reserves (among the largest in the world), low production costs, the proximity of its core markets and the use of its spare capacity it can deter the entry of new competitors through a "price war" (see Box 2) or by modifying the investment behavior of its main

\footnotetext{
15 The US currently has LNG export capacity of about $26 \mathrm{Bcm}$ (three trains at Sabine Pass and Cove Point) which will be supplemented, between now and the end of 2019, by a further $71.8 \mathrm{Bcm}$ (projects under construction), making a total of $100 \mathrm{Bcm}$ by 2020. This could rise to $300 \mathrm{Bcm}$ by 2030 .
} 
competitors. In the context of a specific EU gas market - spot markets and long-term contracts with a surplus supply and not fully globalized - Gazprom can modify the balance of supply and demand on spot markets by using (or not) its spare capacity ${ }^{16}$.

\section{Box 2: The competitiveness of Russian gas exports and US LNG exports}

Estimates of Henderson (2016), Rogers et al. (2015) give a marginal cost for Russian gas deliveries (to the German border) of under \$4/MBtu (\$3.5/MBtu in early 2016) ${ }^{17}$. If Gazprom's main shareholder, the Russian State, considers that maintaining Russia's market share is a priority, it may agree to reduce fiscal pressure on exports, in particular export duty. Without this tax, the delivery cost to the EU in early 2016 would only have been \$3.1/MBtu (Corbeau and Yermakov, 2016). These estimates must be compared with those for the cost of US LNG exports to the EU, in particular under a Cheniere-type contract (Sabine Pass). Starting from a Henry-Hub gas price of $\$ 1.9 / \mathrm{MBtu}$, we obtain a total delivery cost to the EU between $\$ 5.7$ and $\$ 6.4 / \mathrm{MBtu}^{18}$. So in May 2016 the latter cost exceeded of the NBP spot price (\$4.3/MBtu) and the price of Gazprom long-term contracts (to the German border). In the case of new US 'greenfield' LNG projects, delivery costs would be substantially higher $(\$ 8-\$ 10 / \mathrm{MBtu})$ as they would have to cover the entire investment cycle, unlikely Sabine Pass LNG ${ }^{19}$.

By this way, the firm can increase the market uncertainties and discourage the entry of new competitors (US LNG). This unusual spare capacity for a gas market result of an oversupply compared to Russian gas demand and the emergence of new Russian gas companies $^{20}$. Until then analysed as a constraint due to poor investment choices, Gazprom's spare capacity could prove to be a major strategic advantage against US LNG.

At the same time, Gazprom has significantly shifted its position on price indexation formulas in its long-term contracts. It now favours a price system that combines spot prices (on gas hubs) and oil prices (Burmistrova, 2016; Komlev, 2016). In the 2018 settlement of its dispute with the EU Competition Directorate, over 'abuse of dominant market position' (particularly partitioning markets and unfair prices) in eight central and eastern European countries, Gazprom agreed to add competitive 'price benchmarks' to its contracts (Stern and Yafimava, 2017). This implies specific reference to spot-market prices and to prices in its western European contracts. Gazprom has also accepted the other demands made by the Directorate (deleting territorial restriction clauses, changing points of delivery...).

\footnotetext{
${ }^{16}$ Studies on the role of spare capacity (cost-free surplus production capacity) tend to show that as a strategy an incumbent may (or may not) use such capacity to prevent market entry by a competitor (see, for example, Spence, 1997).

${ }^{17}$ These estimate are based on a marginal gas field production cost of $\$ 0.36 / \mathrm{MBtu}$, to which is added the Mineral Extraction Tax $(\$ 0.35 / \mathrm{MBtu})$, the cost of transport inside Russia $(\$ 0.81 / \mathrm{MBtu})$ and then via NordStream (\$1.20/MBtu), plus export duty.

${ }^{18}$ Starting from a (variable) natural-gas price at Henry Hub, we add liquefaction costs between $\$ 2.25$ and $\$ 3 / \mathrm{MBtu}$, the cost of sea transport at \$1/MBtu and regazification $\$ 0.5 / \mathrm{MBtu}$.

${ }^{19}$ This LNG plant is very specific. It benefits from existing infrastructure and constrained customers. Future US projects will be more expensive.

20 "Independents" and oil companies (including Rosneft) with significant gas production have been able to compete with Gazprom on the Russian gas market. In 2016, these actors provided $40 \%$ of the Russian demand.
} 
The firm is also experimenting more flexible ways of commercializing its gas, further proof of its determination to adapt to the EU gas market. As yet, it has only sold relatively small volumes on spot markets: $17 \mathrm{Bcm}$ in 2015, or $8 \%$ of its overall sales (Henderson, 2016). Since 2015 , it has increasingly used the auction mechanism to take advantage of price increases in the spot markets. This was particularly the case in 2018 marking a strategic shift. Since August 2018, Gazprom Export experiments an electronic sales platform intended to supply more gas to European consumers. The St. Petersburg International Mercantile Exchange (SPIMEX) could also serve as a platform for exchanges with Europe, although we are still far from such a configuration allowing a connection of the Russian and European gas markets (Henderson et al., 2018). The spotmarket sales will not take the place of long-term contracts; they supplement rather than replace volumes covered by contract.

Gazprom seems set on maintaining its spare capacity. It steps up development of the Bovanenkovo gas field to achieve an output of $115 \mathrm{Bcm}$ by 2020 (instead of 2022 as initially planned). This additional production would be fed into the Nord Stream I and II pipelines connecting to Germany. Their annual capacity is expected to reach $110 \mathrm{Bcm}$ by the end of 2019. Doubling Nord Stream capacity is entirely consistent with a competitive rationale, enabling Gazprom to deliver substantially higher volumes to EU markets, which in turn would increase the spot markets liquidity. Finally, the Russian company is making considerable changes to its organization and restructuring export activities in a drive to optimize operations and boost efficiency.

It thus appears that a process of coevolution behavior-institution is at work. After a phase essentially reactive, Gazprom engages a proactive hybridization of its model of regulation. International interdependence makes hybridization inevitable as institutional arrangement is applied by an actor other than the designer. Ultimately, the interdependence results in a hybridization of the European model.

\subsection{A more political economic basis for the European Union's competitive regime?}

The competitive dynamic generates a co-evolution of EU's behaviors-institutions because of its antithetical effects. It gives rise to efficiency gains, with gas supply being made by the most competitive supplier, Gazprom. It has also a pro-competitive effects (Krugman, 1979; Krugman and Obstfeld, 1996) because the international contestability of markets leads firms (including those with market power), to reduce their margins so as not to lose market share or not to make the market attractive to new competitors. Consequently, Gazprom has a significate market share but it is not a price maker. Being in a competitive environment, it is forced to cap its price based on the cost of delivery of its main competitors.

Therefore, the EU's willingness to limit Gazprom's market share is not related to market equilibrium factors, but reflects political economy considerations. This leaves the EU in a dilemma: either it can enjoy the cheapest supply of gas, which corresponds in theory to the objectives of its strategy on competition, or it can restrict Russia's market share by giving priority to a more costly source of supply (for example the US LNG). The competitive dynamic consolidates Gazprom's market share de facto. This explains why 
the company now endorses the competitive norm, going so far as to open a new channel for exports by which it can contribute to the liquidity of the northern European market ${ }^{21}$. Regarding this new gas market political economy, does the European Community has other option than relaunching bilateral talks with Russia? Are we going to witness a hybridization of its model that, while remaining liberal, will give place to a mercantilist behavior $^{22}$ ? The EC intends to maintain its preference for a competitive regulation as the Gas Model Target ${ }^{23}$ shows it. It is aiming to increase market integration in order to achieve an Energy Union whose purpose is to reconcile security of supply, structural competitiveness and sustainable development. Carrying out this project, given the limits of the original framework, implies a change within the competitive regime, not a change of the competitive regime.

This hybridization of the European model is likely to take two paths.

In the first, it should refer to EU's legislation on competition. Articles 101 to 105 of the Treaty on the Functioning of the European Union codify business practices and situations of market dominance. Article 102 defines a dominant position with reference to holding market share. This is usually at least $40 \%$ in the energy sector. This would mean the Commission limiting ad hoc Gazprom's market share to less than 40\%. Achieving this goal would require a bilateral political compromise, but would open the way for a possible (re)definition of the market share of each of the EU's gas suppliers.

The second approach to limiting Gazprom's market share would involve opening talks on the issue of infrastructure. Russia's supply of gas to the EU is mainly dependent on pipelines. This is why the Commission is opposed to plans to build Nord Stream II. As a business project the extension to the original pipeline (Nord Stream I) falls largely outside the jurisdiction of EU member states (Fischer, 2017): it does not involve any funding from the EU or individual member states; nor is it dependent on any multilateral agreement between states. As it is located in international waters, the pipeline is subject to international regulations, in particular the United Nations Convention on the Law of the Sea. Therefore, it cannot be challenged on the grounds that it infringes the core principles of EU law. Furthermore, the Legal Service of the Council of the European Union has advised that, in so far as it opens an additional channel for imports, it poses no problem for security of supply to the EU (Yafimava, 2017). In its assessment the Legal

\footnotetext{
${ }^{21}$ Some studies appear to show that building Nord Stream 2 would contribute to lower prices as far as it would limit LNG imports and boost purchases of cheaper Russian gas. See Hecking and Weiser (2018).

${ }^{22}$ We are referring to the S. Andersen, A. Goldthaud and N. Sitter thesis (2017) that the EU is evolving towards liberal mercantilism in terms of energy regulation. The expression liberal mercantilism is to describe the institutional changes at work in the global political economy. Concerning EU, we do not think that its approach is changing towards an approach in terms of power. Rather there is a hybridization of its original model of regulation in order to take into account a less asymmetrical and more heterogeneous political economy and changes in the fundamentals of the gas market. Moreover, it seems wrong to consider that the previous model is devoid of power issues. We have shown that "market size", achieved through competitive integration, provides a comparative advantage for EU countries to influence the preferences and behaviors of other countries, which constitutes, according to the typology of J. Nye (2004), the example of a "hard power".

23 The "Gas Target Model" - defined by the Council of European Energy Regulators, approved in March 2012 at the 21st Madrid Forum - outlines the architecture of a single liberalized European gas market. To date, it is devoting a model of natural gas trading across the EU based on the creation of a limited number of interconnected trading areas.
} 
Service stated that the Third Energy package provided no legal basis for the mandate demanded by the Commission to open negotiations with Russia on how the Directive should apply to Nord Stream; the only basis could be political (Yafimava, 2017; Talus, $2017)^{24}$.

Thus, the dynamics of the competitive regulation initiated by the EU leads to an unanticipated result. The EU faces a dilemma whose resolution implies a hybridization of its energy governance model

\section{Conclusion}

This article raises the issue of the internationalization of regulatory regimes by focusing on the concrete modalities for building the EU-Russia gas interdependence. We hypothesize that the distributive and productive conflicts of interdependence lead actors to hybridize their regulatory model. Our analysis highlights three results.

Firstly, the hybridization of the EU's competitive gas regulatory model results from the interaction of four factors: i) Evolution of the balance of power relations between the two players (EU and Russia); (ii) Evolution of the gas markets (supply, demand) and of competition (iii) Distributional effects of the institutional arrangement implemented; and (iv) How actors implements institutional arrangements. The first two factors go beyond the strict framework of the EU-Russia gas interdependence. Nevertheless, they constitute parameters that can be instrumentalised by the actors to drive a change in the last two factors.

Then, the size of the EU market obliges Gazprom to adapt to the new rules and conditions in force there. Setting aside geopolitical constraints, the Russian company would gain from more assertive integration in the EU's competitive game. In view of its comparative advantages, it could advantageously launch a price war, but also strategies that are more complex. The Russian gas company came about through reform of the Soviet organizational model, but is now emerging as a new actor in the relation of interdependence, able to define its own strategy alongside the goals of the Russian State. Finally, the behavior-institution coevolution highlights a dynamic of hybridization. In the interdependence, more commercial and competitive strategy seem increasingly preponderant for Gazprom confronted with a more competitive environment at home and in the EU. In the same time, the EU has to make adjustments to the rules. There is no certainty that competition alone will be sufficient for the EU to contain the Gazprom's market share. Yet, on the grounds of energy security, this seems to become the EU's unspoken, though now increasingly explicit, goal. Compared to the 1990s, issues of political economy and distributional factors seem increasingly important in the European policy at least concerning its external natural gas supply.

Our analysis of the hybridization leaves two questions open. The first is about the degree of politicization of the European market in the face of the US market access strategy. US LNG exports could be an alternative to Russian gas. They are an element of the EU's supply security. Nevertheless, they would pose a problem of supply costs in addition to the need to develop regasification infrastructures. The second question is about gas

\footnotetext{
${ }^{24}$ The EU's gas directives could be modified. The rules applying to intra-European pipelines could be
} extended to pipelines from third countries. This paves the way for the realization of Nord Stream 2. 
markets evolutions: are we sure that US LNG exports will move to Europe if the Asian market offers better profitability?

\section{Bibliography}

Amable, B., 2016. Institutional complementarities in the dynamic comparative analysis of capitalism. Journal of Institutional Economics, 12, (1), 79-103.

Andersen, S., Goldthaud, A., Sitter, N. (eds.), 2017. Energy Union. Europe's New Liberal Mercantilism? Palgrave MacMillan, London.

Andersen, S., Sitter, N., 2016. The external reach of the EU regulatory state: Norway, Russia and the security of natural gas supplies. In Peters, I. The European Union's Foreign Policy in Comparative Perspective Beyond the 'actorness and power' debate. UACES Routledge, Contemporary European Studies, pp. 80-97.

Austvik, O., Lembo, C., 2017. EU-Russian Gas Trade and the Shortcomings of International Law. Journal of World Trade, 51(4), 645-674.

Baldwin, R., Nelson, D., Ricardson D., 1992. The Political Economy of International Market Access. World Economy, 15(6), November, 679-683.

Boussena, S., 1999. New European Gas Market : Gas Strategies of Other Present and Potential Suppliers, The 1999 International Conference : The role of Russian and CIS Countries in Deregulated Energy Markets (The Moscow International Energy Club et le Centre de Géopolitique des Matières Premières-Université Paris Dauphine), Paris, 6-7 December.

Boussena, S., Locatelli, C. 2017. Gazprom and the complexity of the EU gas market: A strategy to define. Post Communist, 29(4), 549-564.

Boussena, S., Locatelli, C. (2013). Energy institutional and organisational changes in EU and Russia : Revisiting gas relations. Energy Policy, vol. 55, pp. 180-189

Boyer R., 2015. Économie politique des capitalismes. Théorie de la régulation et des crises. Paris, La Découverte.

Boyer R., 2004. Une théorie du capitalisme est-elle possible ?. Paris, Odile Jacob.

Boyer R., 2003. Les analyses historiques comparatives du changement institutionnel: quels enseignements pour la théorie de la régulation?. L'Année de la Régulation, 7, 2003-2004, 167203.

Boyer, R. \& Saillard, Y. (eds.) (2002). Regulation Theory. The State of the Art. London: Routledge.

Boyer, R. (2000). The Political in the Era of Globalization and Finance: Focus on some Regulation School Research. International Journal of Urban and Regional Studies, 24(2), 274-322.

Boyer R. et alii (eds.), 1998. Between Imitation and Innovation. Oxford, Oxford University Press.

Boyer, R. (1990). The Regulation School: a Critical Introduction. New-York: Columbia University Press.

Brander, J. A., Spencer, B. J., 1985. Export Subsidies and International Market Share Rivalry. Journal of International Economics, 18

Buch-Hansen, H., Wigger, A., 2010. Revisiting 50 years of market-making: The neoliberal transformation of European competition policy. Review of International Political Economy, 17(1), 20-44.

Burmistrova, H., 2016. Ensuring the Russian-EU Energy Cooperation. European Gas Conference, Vienne, 20 January.

Casier, T., 2011. The Rise of Energy to the top of the EU-Russia Agenda : From Interdependance to Dependance ?. Geopolitics, 16, 536 -552. 
CEC (Council of the European Communities), 1988. The Internal Energy Market, COM (88) 238, available at http://aei.pitt.edu/4037/1/4037.pdf (accecced January 2019)

Cecchini, P., Catinat, M. Jacquemin, A., 1998. The European Challenge 1992: The Benefit of a Single Market. Aldershot, Wildwood House, London.

Corbeau, A., Yermakov, V., 2016. Will There Be a Price War Between Russian Pipeline Gas and US LNG in Europe? KAPSARC, KS-1646-DP037A.

Cottier, T., Matteotti-Berkutova, S., Nartova, O., 2010. Third Country relations in EU Unbunbdling of Natural Gas Markets: The « Gazprom Clause » of Directive 2007/73 EC and WTO Law. Nncr Trade regulation, World Trade Institute, Working Paper $n^{\circ}$ 2010/06.

Creti, A., Villeneuve, B., 2004.Long term contracts and take or pay clauses in natural gas markets. Energy Studies Review, 13(1), 75-94.

Damro, C. (2006). The New Trade Politics and EU Competition Policy: Shopping for Convergence and Cooperation, Journal of European Public Policy, 13(6), 867-886.

Damro, C., 2015. Market power Europe: exploring a dynamic conceptual framework. Journal of European Public Policy, 22(9), 1336-1354.

Djelic, M-L., Quack, S., 2003.Theoretical Building Blocks for a Research Agenda Linking Globalization and Institutions. In Djelic, M-L., Quack, S. eds. Globalization and Institutions. Cheltenham, Edward Elgar, 15-35.

Drexl, J., 2011. La constitution économique européenne. L'actualité du modèle ordo-libéral. Revue International de Droit Economique, 25(4), 419-454.

EC (2015). Energy Union Package. A Framework Strategy for a Resilient Energy Union with a Forwardlooking Climate Change Policy. Communication from the Commission to the European Parliament, the Council, the European Economic and Social Committee, the Committee of the Regions and the Eropean Investment Bank, available at https://eur-lex.europa.eu/resource.html?uri=cellar:1bd46c90bdd4-11e4-bbe1-01aa75ed71a1.0001.03/DOC_1\&format=PDF

EC (2010). Communication from the Commission. Energy 2020: a Strategy for Competitive, Sustainable ans Secure Energy, COM (2010) 639, Brussels, European Commission.

EC (2006). European Strategy for Sustainable, Competitive and Secure Energy. European Commission, available at http://europa.eu/documents/comm/green_papers/pdf/com2006_105_en.pdf

Ehkrman, C. D., 1992. The Contribution of Competition Policy to the Single Market. Common Market Law Review, 29(2), 257-282.

Farrell, H., Newman, A. 2016. The New interdependance approach : theoretical development and empirical demonstration. Review of International Political Economy, 23, (5), 713-736.

Feenstra, R., 2003. Advanced International Trade. Theory and Evidence. Princeton University Press, Princeton.

Fischer, S., 2017. Lost in Regulation: The EU and Nord Stream 2. CSS, Policy Perspectives, 5(5), Novembre.

Gerber D. J., 1994. Constitutionalizing the Economy: German Neo-Liberalism, Competition Law and the "New" Europe. American Journal of Comparative Law, 42(1), 25-84.

Gilpin R. (1987). The Political Economy of International Relations. Princeton, Princeton University Press.

Godzimirski, J. (2015). Russia-EU Energy Relations: From Complementarity to Distrust ?. In Godzimirski, J. Ed. EU Leadership in Energy and Environmental.

Goldthau, A., Sitter, N., 2015a. A liberal actor in a Realist World: The European Union Regulatory State and the Global Political Economy of Energy. Oxford: Oxford University Press.

Goldthau, A., Sitter, N., 2015b. Soft power with a hard edge: EU policy tools and energy security. Review of International Political Economy, 22, (5), 941-965.

Gomory R. E., Baumol W.J., 2000. Global Trade and conflicting National Interest. Cambridge, Cambridge University Press. 
Graham, E., Lawrence, R. (1996). Measuring the International Contestability of Markets. A Conceptual Approach, Journal of World Trade, 30(5), 5-20.

Grossman G., Helpman, E. (1991). Innovation and Growth in the Global Economy, Cambridge, MIT Press.

Hall P. A. (1986). Governing the Economy: The Politics of State Intervention in Britain and France, New York, Oxford University Press.

Harsem, O., Claes D H., 2013. The interdependance of european-Russian energy relations. Energy Policy, 58, 784-791.

Hecking, H., Weiser, F., 2017. Impacts of Nord Stream 2 on the EU Natural Gas Market. Ewi Energy Research \& Scenarios, http://www.ewi.research-scenarios.de/team/dr-harald-hecking/

Henderson, J., Mitrova, T., Heather, P., Orlova, E., Sergeeva, Z., 2018. The SPIMEX Gas Exchange: Russian Gas Trading Possibilities. OIES paper: NG 126, The Oxford Institute For Energy Studies, January.

Henderson, J., 2016. Gazprom - Is 2016 the Year for a Change of Pricing Strategy in Europe ?. Oxford Energy Comment, Oxford Institute For Energy Studies.

Henderson, J., Mitrova, T., 2015. The Political and Commercial Dynamics of Russia's Gas Export Dynamic. Oxford Institute For Energy Studies. OIES Paper no. NG 102.

Howse, R., Nicolaïdis, K. (2003). Enhancing WTO Legitimacy: Constitutionalization or Global Subsidiarity?. Governance, 16(1), 73-94.

Hubbard, G., Weiner, R. (1986). Regulation and Long term Contracting in US Natural Gas Markets. Journal of Industrial Economics, 35(1), 47-83.

Jansen, T., Van Lier, A., Van Witterloostuijin, A., Von Ochssée, T., 2012. A modified Cournot model of the natural gas market in the European Union: Mixed-motives delegation in a politicized environment. Energy Policy, 41, 280-285.

Jessop, B. (ed.) (2001). Regulation Theory and the Crisis of Capitalism. Vol. 1 \& 5, Elgar Reference Collection. Cheltenham: Edward Elgar.

Jessop, B. \& Sum, N. (2006). Beyond the Regulation Approach. Putting Capitalist Economies in their Place. Cheltenham: Edward Elgar.

Kaplow, L., 2015. Market definition, market power, International Journal of Industrial Organization, 43, 148-161.

Keating, M., 2012. Re-thinking EU Energy Security: The Utility of Global Best practices for Successful Transnational Energy Governance. In Kuzemko, C., Belyi, A., Goldthau, A., Keating, M. (eds). Dynamics of Energy Governance in Europe and Russia. Palgrave MacMillan.

Keohane, R.O., 2002. Power and Governance in a Partially Globalized World, Routledge, London.

Keohane, R.O., Nye, J., 1977. Power and Interdependence: World Politics in Transition, Boston, MA: Little, Brown.

Knight J., 1992. Institutions and Social Conflict. New York, Cambridge University Press.

Komlev, S., 2016. Oil indexation: The best remedy for market failure in the natural gas industry. Demian Literary Agency, St Pétesbourg, October.

Kratochvil, P., Tichy, L., 2013. EU and Russia discourse on energy relations. Energy Policy, 56,. 391-406.

Krugman, P., 1979. Increasing Returns, Monopolistic Competition and International Trade. Journal of International Economics, 9(4), 469-479.

Krugman, P., 1980. Scale Economies, Product Differentiation, and the Pattern of Trade. American Economic Review, 70, 950-959.

Krugman, P., 1984. Import Protection as Export Promotion: International Competition in the Presence of Oligopoly and Economies of Scale. In H. Kierzkowski (ed.). Monopolistic Competition in International Trade. Oxford, Oxford University Press.

Krugman, P. Helpman, E., 1985. Market Structure and Foreign Trade: Increasing Returns Imperfect Competition and the International Economy. Cambridge, Cambridge, MIT Press.

Krugman, P. Obstfeld, M., 1995. International Economics. Addison Wesley, New York.

Kuzemko, C., 2014. Ideas, power and change: explaining EU-Russia energy relations, Journal of European Public Policy, 21(1), 58-75. 
Kuzemko, C., Belyi, A., Goldthau, A., Keating, M. eds., 2012. Dynamics of Energy Governance in Europe and Russia. Palgrave MacMillan.

Lavenex, S., Schimmelfenning, F., 2009. EU rules beyond EU borders: theorizing external governance in European politics, Journal of European Public Policy, 16(6), 791-818.

Lavanex, S., 2004. EU external governance in « Wider Europe ». Journal of European Public Policy, 11(4), 680-700.

Locatelli, C., 2014. The Russian gas industry: challenges to the 'Gazprom model?. Post Communist Economies, 26(1), 53-66.

Mahoney J., Thelen, K., 2010. Explaining Institutional Change. Ambiguity, Agency, and Power. Cambridge, Cambridge University Press.

Manners, I., 2002. Normative power Europe: a contradiction in termes ?. Journal of Common Market Studies, 40(2), 235-258.

McGowan, F., Wallace, H., 1996. Towards a European Regulatory State. Journal of European Public Policy, 3(4), 560-576.

Meunier, S., Nicolaïdis, K., 2006. The European Union as a conflicted trade power. Journal of European Public Policy, 13(6), 906-925.

Newmann, A., Posner, E., 2015. Putting the EU in its place: policy strategies and the global regulatory context. Journal of European Public Policy, 22(9), 1316-1335.

North, D., 1990. Institutions, Institutional Change and Economic Performance. Cambridge: Cambridge University Press.

Nye, J. S., 2004. Soft Power: the Means to Success in World Politics. New York, Public Affairs.

Nyssens, H., Cultreta, C., Schnichels, D., 2004. The territorial restrictions case in the gas sector: a state of play. Competition Policy Newsletter, 1, 48-51.

Palan R., 2000. Global Political Economy: Contemporary Theories. London, Psychology Press.

Palley, T. J., 2006. Rethinking Trade and Trade Policy. Public Policy Brief 86-2006, The Levy Economics Institute of Bard College.

Roccu, R., 2018. Ordoliberalizing the Neighbourhood? The EU's Promotion for Regulatory Reforms in Egype. Journal of Common Market Studies, 56(5), 1070-1086.

Rogers, H. (2017). Qatar Lifts its LNG moratorium. Oxford Institute For Energy Studies. Oxford Energy Comment. April.

Rogers, H., Stokes, D., Spinks, O., 2015. Russia's strategic response to an oversupplied gas market. Timera Energy, 23 novembre.

Romanova, T., 2014. Russian energy in the EU market: Bolstered institutions and their effects. Energy Policy, 74, 44-53.

Sagen, E., Tsygankova, M., 2008. Russian natural gas exports-Will Russian gas price reforms improve the European security of supplys ?. Energy Policy, 36, 867-880.

Skalamera, M., 2016. Invisible but not indivisible: Russia, the European Union, and the importance of 'Hidden Governance'. Energy Research \& Social Science, 12, 27-49.

Smith, M., 1996. The European Union and Changing Europe: Establishing the Boundaries of Order. Journal of Common Market Studies, 34(1), 5-28.

Spence, M., 1997. Entry, Capacity, Investment and Oligopolistic Pricing. Bell Journal of Economics, 8(2), 534-544.

Stern, J., Yafimava, K., 2017. The EU Competition investigation of Gazprom's sales in central and eastern Europe: a detailed analysis of the commitments and the way forward. OIES paper: NG 121, Oxford Institute For Energy Studies.

Talus, 2017. Decades of EU energy policy: towards politically driven markets. Journal of World Energy Law and Business, 10, 380-388.

Thelen, K., 2009. Institutional Change in Advanced Political Economies. British Journal of Industrial Relations, 47(3), 471-498.

Thelen, K., 2003. How Institutions Evolve: Insights from Comparative Historical Analysis. In J. Mahoney et D. Rueschenmeyer (eds.). Comparative Historical Analysis in the Social Sciences. Cambridge University Press, New York. 
Thelen, K., 1999. Historical Institutionalism in Comparative Politics. Annual Review of Political Science, 2, 369-404.

Van Der Meulen, E., 2009. Gas supply and EU-Russia Relations. Europe-Asia Studies. 61(5), 833-856.

Vavilov, A. (ed.), 2014. Gazprom. An Energy Giant and Its Challenges in Europe, Palgrave MacMillan, London.

Willems, A., Sul, J., Benizri, Y., 2010. Unbundling as a Defence Mechanism against Russia: Is the EU Missing the Point?. In Talus, K., Fratini, P. (Eds). EU-Russia Energy Relations. OGEL collection, Euroconfidential, 227-244.

Yafimava, K., 2017. The Council Legal Service's assessment of the European Commission's negotiating mandate and what it means for Nord Stream 2. Energy Insight: 19, Oxford Institute For Energy Studies.

Yang, Z., Zhang, R., Zhang, Z., 2016. An exploration of a strategic competition model for the European Union 
Table 1 : Evolution of Gazprom's market share in EU gas imports

\begin{tabular}{|l|l|l|l|l|l|}
\hline$\%$ & Russia & Norway & Algeria & Qatar & Others \\
\hline $\mathbf{2 0 1 7}$ & 41,0 & 30,2 & 12,1 & 5,8 & 10,9 \\
\hline $\mathbf{2 0 1 4}$ & 38,9 & 33,5 & 29,01 & 21,68 & 10,7 \\
\hline $\mathbf{2 0 1 0}$ & 32,5 & 30,4 & 15,5 & 10,3 & 11,3 \\
\hline $\mathbf{2 0 0 4}$ & 47,4 & 27,1 & 19,1 & 1,4 & 4,9 \\
\hline
\end{tabular}

Source: From BP data . Statistical Review of World Energy, different years 